\title{
UGT2B17 wt Allele
}

National Cancer Institute

\section{Source}

National Cancer Institute. UGT2B17 wt Allele. NCI Thesaurus. Code C105424.

Human UGT 2B17 wild-type allele is located in the vicinity of 4 q13 and is approximately 31 $\mathrm{kb}$ in length. This allele, which encodes UDP-glucuronosyltransferase 2B17 protein, is involved in the catabolism of xenobiotics and steroids. Copy number variation of the gene is associated with aberrant bone mineral density quantitative trait which can lead to osteoporosis. 